\title{
Impact of climate change on landslides in Slovenia in the mid-21st century
}

\author{
Vpliv podnebnih sprememb na pojavljanje zemeljskih plazov \\ v sredini 21. stoletja v Sloveniji
}

\author{
Mateja JEMEC AUFLIČํㄹ ${ }^{1}$ Gašper BOKAL ${ }^{1}$, Špela KUMELJ ${ }^{1}$, Anže MEDVED², \\ Mojca DOLINAR ${ }^{2}$ \& Jernej JEŽ ${ }^{1}$
}

\begin{abstract}
${ }^{1}$ Geological Survey of Slovenia, Dimičeva ulica 14, SI-1000 Ljubljana, Slovenija; e-mail: mateja.jemec@geo-zs.si, gasper.bokal@geo-zs.si, spela.kumelj@geo-zs.si, jernej.jez@geo-zs.si ${ }^{2}$ Slovenian Environment Agency, Vojkova 1b, SI-1000 Ljubljana, Slovenija; e-mail: anze.medved@gov.si, mojca.dolinar@gov.si
\end{abstract}

Prejeto / Received 3. 8. 2021; Sprejeto / Accepted 13. 10. 2021; Objavljeno na spletu / Published online 28. 12.2021

Key words: climate change, landslides, models, hazard, prediction

Ključne besede: podnebne spremembe, zemeljski plazovi, modeli, nevarnost, napoved

\begin{abstract}
Slovenia is affected by extreme and intense rainfall that triggers numerous landslides every year, resulting in significant human impact and damage to infrastructure. Previous studies on landslides have shown how rainfall patterns can influence landslide occurrence, while in this paper, we present one of the first study in Slovenia to examine the impact of climate change on landslides in the mid-21st century. To do this, we used the Representative Concentration Pathway (RCP) 4.5 climate scenario and future climatology simulated by six climate models that differed from each other as much as possible while representing measured values of past climate variables as closely as possible. Based on baseline period (1981-2010) we showed the number of days with exceedance of rainfall thresholds and the area where landslides may occur more frequently in the projection period (2041-2070). We found that extreme rainfall events are likely to occur more frequent in the future, which may lead to a higher frequency of landslides in some areas.
\end{abstract}

\section{Izvleček}

Vsako leto Slovenijo prizadenejo ekstremne in močne padavine, ki sprožijo številne zemeljske plazove, kar povzroči znaten vpliv na človeka in škodo na infrastrukturi. Prejšnje študije plazov so pokazale, kako padavine vplivajo na pojav plazov, medtem ko v tem prispevku predstavljamo eno izmed prvih študij v Sloveniji, ki proučuje vpliv podnebnih sprememb na zemeljske plazove sredi 21. stoletja. V ta namen smo uporabili scenarij značilnih potekov vsebnosti toplogrednih plinov (RCP4.5) in uporabili simulacije šestih podnebnih modelov, ki so se med seboj čimbolj razlikovali, hkrati pa kar najbolj enako predstavljali izmerjene vrednosti podnebnih spremenljivk v obdobju meritev. Na podlagi referenčnega obdobja (1981-2010) prikazujemo število dni, ko padavine presežejo sprožilne količine padavin in območja, kjer se lahko plazovi v projekcijskem obdobju (2041-2070) pogosteje pojavljajo. Rezultati kažejo, da se bodo ekstremni padavinski dogodki v prihodnosti zelo verjetno pojavljali pogosteje kot danes, kar lahko na nekaterih območjih povzroči pogostejše pojavljanje zemeljskih plazov.

\section{Introduction}

Landslides pose a serious threat to populations worldwide, causing fatalities, property damage, and significant economic losses. The occurrence of landslides is influenced by several factors related to the stability of the slopes. Among the most important triggers is rainfall, which is one of the fundamental climate variables. In a chang- ing climate, the frequency and intensity of rainfall events are expected to increase, although in some places the average amount of rainfall would not show any significant change.

The first beginnings of research on the effects of climate change on slope instabilities and landslides, as well as model scenario studies, date back to the end of the 20 th century, when 
the ntergovernmental Panel on Climate Change (IPCC) issued the first climate change assessment report Heerdegen (1991). Recently Gariano et al. (2016) published comprehensive research about landslides in a changing climate where research and methods related to climate change impact on landslides are divided into three groups. The first group combines research focus on climate change impact assessment methods. Dikau \& Shrott (1999) analyzed landslide outcomes in Europe in relation to climate change between 1850 and 2000, establishing criteria for (a) landslide identification, (b) past precipitation distribution and relationship to climate variables and landslide phenomena, and (c) development of hydrogeological models to assess climate change impacts. Sidle \& Ochiai (2006) analyzed the processes that cause landslides. They also considered the effects of climate change on tree species growth and land use but pointed out the complexity of the variables studied. McInnes et al. (2007) published the Proceedings of the Participants in the Conference on Landslides and Climate Change (Ventnor, UK). Crozier (2010) examined the mechanisms of landslides and the stability of slopes affected by climate change. Coe \& Godt (2012) identified 14 different methods for estimating the effects of climate change on landslides. They divided all the methods into three groups: a) long-term monitoring of landslide movement, b) feedback analysis, and c) projection analysis. An important finding of all the considered methods is the high uncertainty as a consequence of the prediction of short-term intensive precipitation. On the contrary, studies that attempted to predict landslide activity through changes in air temperature and annual/ seasonal precipitation show less uncertainty. The second group focus on the slope stability assessment with climate projections. Numerous studies have examined the impact of climate change on landslides using the method of empirically upgrading the spatial scale of global circular model simulations (GCM) and using past measurements of meteorological variables as an input for slope stability (Buma \& Dehn, 1998; Collison et al., 2000; Tacher \& Bonnard, 2007; Bonnard et al., 2008; Jakob \& Lambert, 2009; Chang \& Chiang, 2011; Coe, 2012; Comegna et al., 2013; Rianna et al., 2014; Gassner et al., 2015; Alvioli et al. 2016). The main findings of the research are that the intensity and duration of precipitation significantly affect the rise of groundwater and pore pressure in the soil. The third group investigate climate change impacts on slope stability and landslide hazard. The influence of climate and its changes on landslides may be defined in general terms as: (a) local or regional (or global), (b) short-term or long-term impact, (c) direct or indirect. Local influence studies have been investigated using total/cumulative precipitation, precipitation intensity, air temperature, weather system (Collison et al., 2000; Malet et al., 2005; Tommasi et al., 2006; Dixon and Brook, 2007; Rianna et al., 2014; Zollo et al, 2014), regionally for areas ranging from a few $100 \mathrm{~m}^{2}$ to a few $1000 \mathrm{~km}^{2}$ (Rebetez et al., 1997; Malet et al., 2007; Gariano et al., 2015; Ciabatta et al., 2016), nationally or supra-regionally (Sidle \& Dhakal, 2002; Schmidt \& Glade, 2003; Winter et al., 2010; Stoffel et al., 2014; Paranunzio et al., 2016). The short-term impacts of climate change span from a few years to a century or two, while the long-term impacts are measured from several centuries to several millennia (Trauth et al., 2000; Schmidt \& Dikau, 2004; Borgatti \& Soldati, 2010; Yin et al., 2014). Direct impacts of climate are those that directly affect the occurrence of landslides, such as changes in the precipitation regime that affect the amount of precipitation that can cause landslides (Guzzetti et al., 2007; Jakob \& Lambert, 2009; Stoffel et al., 2014). Indirect effects of climate affect environmental and landscape conditions, and these affect landslides, for example, a change in precipitation regime can change the type of land use, leading to a change in slope stability (Glade, 2003; Schmid \& Glade, 2003; Sidle \& Ochiai, 2006; Wasowski et al., 2010).

In Slovenia, the research of climate change impact on landslide occurrences using climate change projections has not yet been studied. Meanwhile Komac (2005), Jemec Auflič \& Komac (2013), Jemec Auflič et al. (2016), Jemec Auflič et al. (2018) research rainfall induced landslides based on evidenced landslide events. The results showed that the main triggering factors for numerous shallow landslides are intensive and prolonged rainfall. These findings contributed to the formation of national rainfall induced landslide warning system (MASPREM) in Slovenia in 2013 (Jemec Auflič et al., 2016, Jemec Auflič et al., 2018) which is continuously being developed and improved. The first rainfall threshold curve for rainfall-induced landslides at the national level was presented by Rosi et al. (2016) using a statistical approach, by Jordanova et al. (2020) using an empirical approach, while Bezak et al. $(2016,2018,2019)$ introduced rainfall thresholds for the smaller regions in Slovenia using mainly hydrological data. However, extreme or intense 
rainfall events trigger more than a hundred landslides in Slovenia every year (Jemec Auflič et al., 2018).

The main objective of this paper is to study climate change impact on landslides in the mid of $21^{\text {st }}$ century in Slovenia. For this purpose, we used the Representative Concentration Pathway climate scenario (RCP4.5), which is considered a moderately optimistic scenario and predict a gradual reduction of emissions and a stabilization of the radiative contribution shortly after 2100 (IPCC, 2018). In detail, we present the number of days with exceedance of rainfall thresholds and the area where landslides may occur more frequently in mid of 21 st century period. We considered RCP4.5 data as the baseline period (19812010) based on which we made the assessment of the impact of climate change on landslides in the future.

\section{Data and methods}

\section{Climate models data}

Climate change scenarios play an important role in the preparation of a landslide risk assessment and adaptation measures. The course of climate change in the future depends on actual current and future greenhouse gas emissions, which are represented by four Representative Concentration Pathway climate scenarios (RCPs). These scenarios are based on human activities and associated emissions of $\mathrm{CO}_{2}, \mathrm{CH}_{4}$ and $\mathrm{N}_{2} \mathrm{O}$, and other air pollutants. The scenarios can be identified by the value of radiative forcing at the end of the $21^{\text {st }}$ century, a measure of enhanced greenhouse effect compared to pre-industrial times in units of watts per metre squared $\left(\mathrm{W} / \mathrm{m}^{2}\right)$ (van Vuuren et al., 2011). Greater radiative forcing implies greater changes in the climate system.
To assess the impacts of climate change up to the 21st century, the Slovenian Environment Agency (ARSO) uses the simulations of regional climate models from the EURO-CORDEX project (Benestad et al., 2018; Bertalanič et al., 2019). For the purpose of this study, we utilized the climate variable precipitation. The horizontal resolution of the regional models used in our study is around $12 \mathrm{~km}$. The modeling period is 1961-2070 for all models and 1971-2070 for some. The time step of the model results is one day. Out of 14 combinations of global and regional climate models, six models (Table 1) were selected that are as different from each other as possible while matching the measured values of climate variables in the past as closely as possible. All of the six models are considered equally reliable or unreliable.

Data were prepared for the moderately optimistic scenario RCP4.5, which assumes significant mitigation measures for greenhouse gas emissions for two time periods, the baseline period (1981-2010) and the projection period (20412070). Daily precipitation data were downscaled from $12 \mathrm{~km}$ resolution to $1 \mathrm{~km}$ (Fig. 1). The downscaling of the data was performed on a daily basis for all six climate models.

Precipitation are calculated based on the maximum amount of precipitation that falls on a single cell over a one-year period. The average for the entire projection area is then calculated based on all annual maximum precipitation. The precipitation projections are overlaid with the rainfall trigger values within the algorithm, which determines the areas where the rainfall thresholds are exceeded and the degree of exceedance.

Table 1. Table of climate models (abbreviations provided by ARSO), which are abbreviations of the meteorological centers that prepared the data (e.g DMI- Danish Meteorological Institute, KNMI-Netherlands Meteorological Institute, SMHI- Swedish Meteorological and Hydrological Institute, IPSL- Institute Pierre-Simon Laplace France). With * we marked the CLMcom centre. The Global Climate Model (GCM) provided boundary conditions, and the Regional Climate Model (RCP) recalculated the data to a smaller scale (about $12 \mathrm{~km}$ ).

Tabela 1. Seznam podnebnih modelov (okrajšave je pripravil ARSO), ki so kratice meteorološkegih centrov, kjer so podatke pripravili (na primer DMI- Meteorološki inštitut Danske, KNMI- Meteorološki inštitut Nizozemske, SMHI- Meteorološki in hidrološki inštitut Švedske, IPSL-Ištitut Pierre-Simon Laplace Francija). Z * je označen center CLMcom. Globalni podnebni model (GCM) je dal robne pogoje, regionalni podnebni model (RCP) pa je preračunal podatke $\mathrm{v}$ manjšo skalo (okoli $12 \mathrm{~km}$ ).

\begin{tabular}{|l|l|l|}
\hline Model & Global climate model (GCM) & Regional climate model (RCM) \\
\hline CCLM1* & CERFACS-CNRM-CM5 & CCLM4-8-17 \\
\hline CCLM2 $*$ & MPI-ESM-LR & CCLM4-8-17 \\
\hline DMI & EC-EARTH & HIRHAM5 \\
\hline IPSL & IPSL-CM5A-MR & WRF331F \\
\hline KNMI & HadGEM2-ES & RACMO22E \\
\hline SMHI & MPI-ESM-LR & RCA4 \\
\hline
\end{tabular}




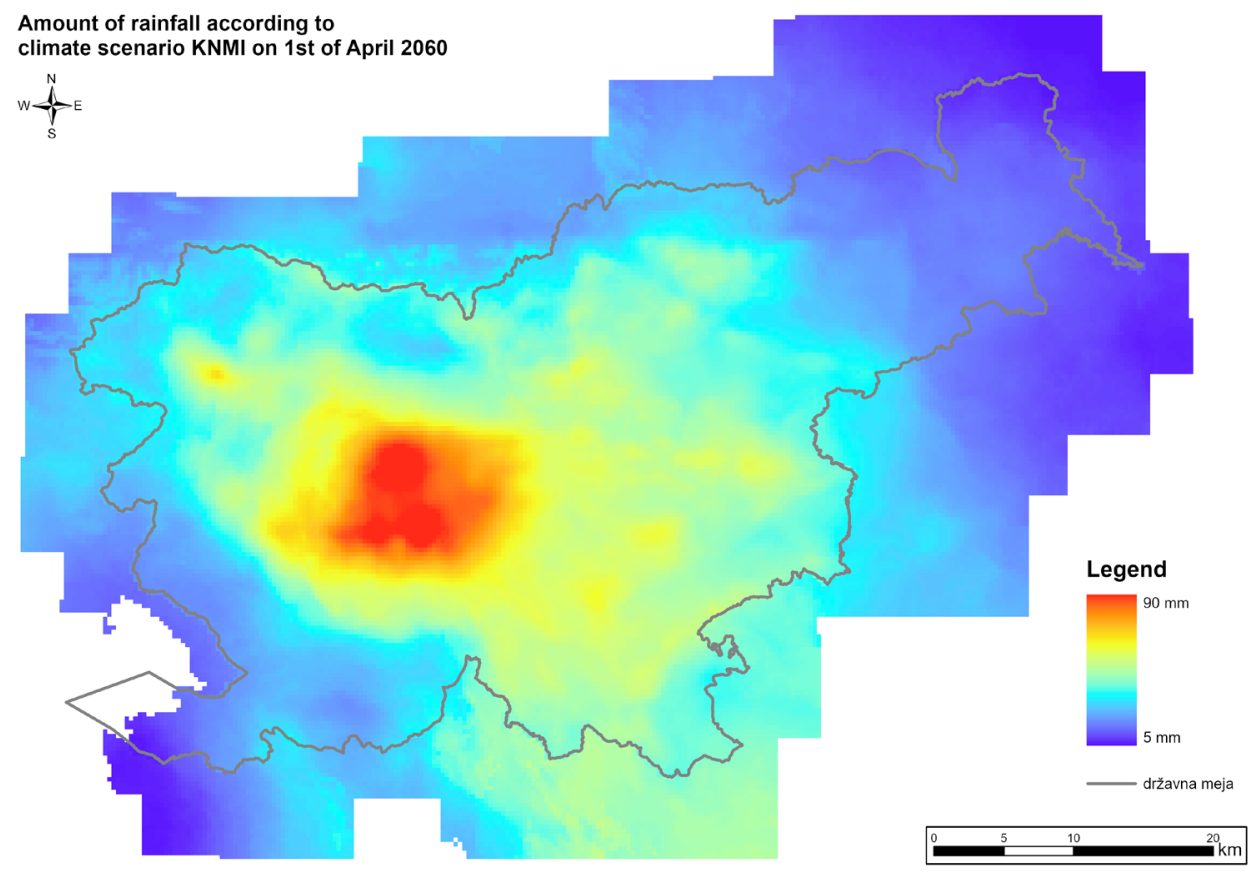

Fig. 1. Example of climate model simulation of daily precipitation downscaled from $12 \mathrm{~km}$ resolution to 1 $\mathrm{km}$ for Slovenia, produced by ARSO.

Sl. 1. Primer dnevnih padavinskih podatkov simuliranih s podnebnim modelom in z zmanjševanjem skale pretvorjenih iz $12 \mathrm{~km}$ ločljivosti v $1 \mathrm{~km}$, ki ga je izdelal ARSO.

\section{Determination of the rainfall frequency and climate change impact on landslides}

Determining the number of days with exceeded rainfall threshold was an important input to the climate change impact assessment. Landslide-triggering rainfall threshold, values determined within the MASPREM system are determined based on engineering-geological map (EG map). EG map was created based on merging the lithology units of Slovenia according to EG characteristics such as soils, soft rocks and rocks; on the basis of their origin and on the basis of the composition, rock strength and particle size ranges (Ribičič et al., 2003). For defining rainfall thresholds, the frequency of spatial occurrence of landslide per spatial unit was correlated with a EG map, and 24-hour maximum rainfall data with the return period of 100 years (Komac et al., 2013; Jemec Auflič et al., 2016). The result of frequency of landslide occurrence and rainfall data provides a good basis for determining the critical rainfall threshold over which landslides occur with high probability. The maximum threshold is defined as the level above which a landslide always occurs (White et al., 1996). In the case of the MASPREM system, the maximum rainfall threshold is $70 \mathrm{~mm}$, especially for the EG units where clayey, slaty clays, marls and scree components predominate.

The number of days with exceeded rainfall threshold for landslide occurrence was determined by an analytical overlap operation following the workflow shown in Figure 2. In the first phase the six time series climate models (RCP4.5) for baseline and projection periods were separated into individual raster's using ArcGIS set tool "Make NetCDF raster layer" (Fig. 2, A), based on which the extreme yearly precipitation events were defined for the individual raster cell. The cells representing areas with exceeded rainfall threshold have value 1 , all other areas were set to 0 . In the second step (Fig. 2, B), we created a threshold event model that determined the number of days with exceeded rainfall thresholds based on rainfall thresholds and extreme yearly precipitation events. The main purpose of the analysis was to determine the difference in the number of days with exceeded precipitation triggers in the projection period (2040-2070) compared to the baseline period (1981-2010). This also gave us an overview of the number of extreme events (whether there will be only one extreme event or several) and where they will occur spatially.

To estimate the impact of climate change on landslides by mid-century, extreme yearly precipitation events were combined into 30 -year maximum precipitation events using the data grouping model (Fig. 2, C). To assess the impact of climate change on landslides, we used the MASPREM system algorithm (Komac et al., 2013; Jemec Auflič et al., 2016). The system predicts rainfall-induced landslides using fuzzy logic based on the 1:250,000 scale landslide susceptibility map, rainfall thresholds and rainfall forecast model. In this paper 30 years of maximum precipitation events were used as input data to replace the ALADIN forecasts used in the MASPREM system (Fig. 2, D). 


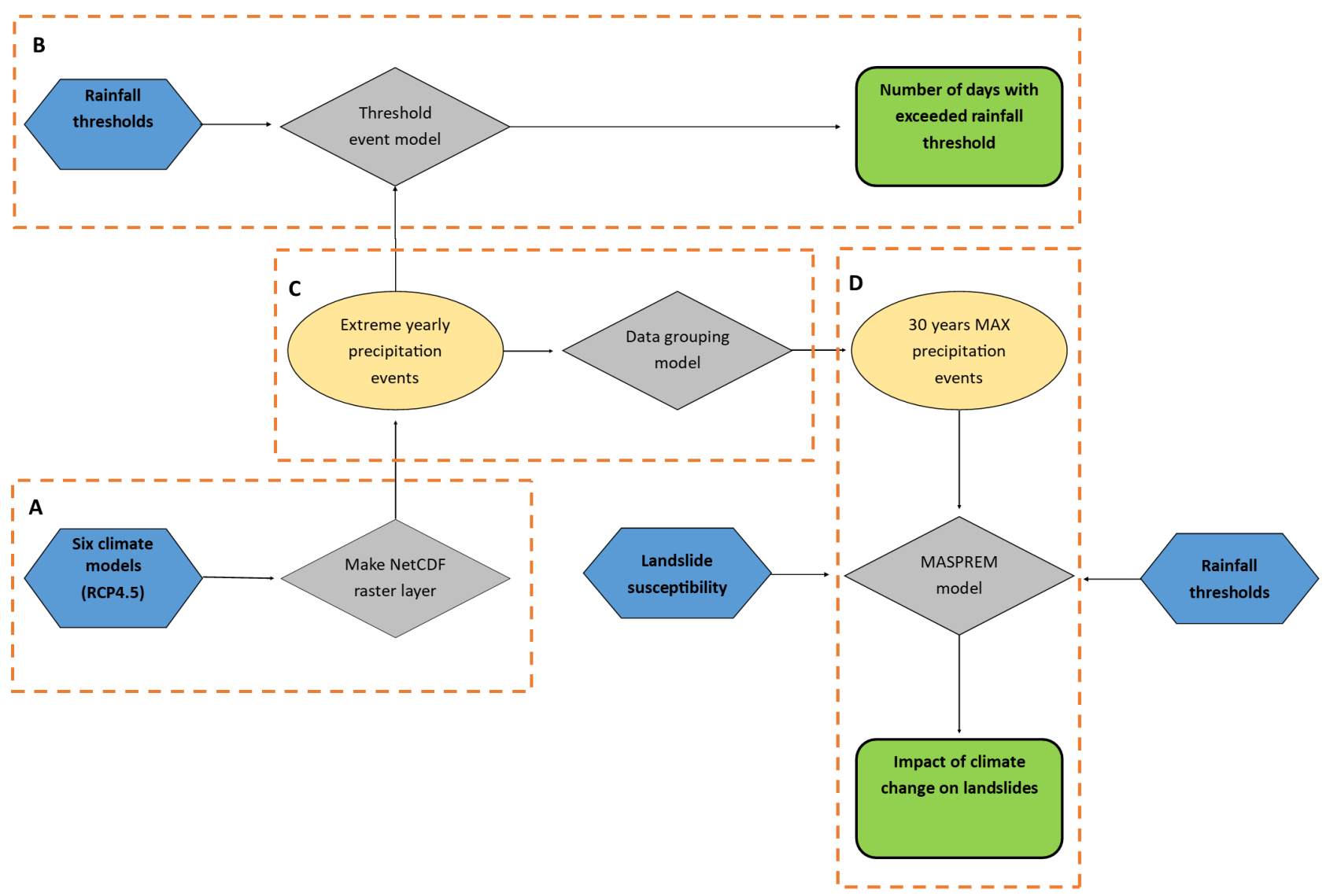

Fig. 2. Workflow to determine the number of days with exceeded rainfall threshold and the impact of climate change on landslides. Letters A, B, C, D indicate different sub-workflows.

Sl. 2. Proces določanja pogostosti padavinskih dogodkov in vpliva podnebnih sprememb na plazove. Oznake A, B, C, D označujejo različne procese.

The MASPREM model was then transformed and written into a Python script, allowing the model to run quickly and reliably. This map was overlaid with rainfall thresholds and processed with a 1: 250,000 scale landslide probability model for Slovenia (Komac \& Ribičič, 2006). The landslide prediction model was converted from a numerical part to a descriptive part and presented in the form of a 5-point scale: 1 - negligible, 2 - low, 3 - medium, 4 - high, 5 - very high probability. The results in the form of map represent the areas where an increased probability of landslides due to changes in precipitation in the period 20412070 can be expected for the entire territory of Slovenia at a scale of 1:250,000.

The ESRI software environment (ArcGIS Pro 2.5.0, ArcGIS Server 10.8) was used to generate landslide probability in baseline and projection periods, input data, and associated statistics. Scripts were created for each content set using the Python programming language, which automated and streamlined the entire process of creating probability projections. The scripts were created in the ArcPy environment, which allowed the use of ESRI software tools outside of the program itself.

\section{Results and discussion}

The results are presented spatially and in tabular form for the whole Slovenian territory for six climate models (CCLM1, CCLM2, DMI, IPSL, KNMI, SMHI) for the moderately optimistic scenario of greenhouse gas emissions (RCP4.5). The maps of climate change impacts on landslides show only landslide source areas, mainly for the shallow landslides, while deep-seated landslides are more difficult to predict with the applied methodology.

\section{The frequency of exceedance of rainfall threshold}

To estimate the number of days with exceeded rainfall thresholds in the projection period (20412070), we compared the number of days when the value of precipitation exceeded $70 \mathrm{~mm}$ in baseline and projection periods. Results are tabulated and spatially presented with the percentage of mid-century area which reflect difference in the number of days with trigger precipitation amounts exceeded between the baseline and projection periods for all six models (Figs. 3, 4). Figure 3 shows the percentage of areas with exceeded rainfall thresholds between the baseline and projection periods for six selected climate 


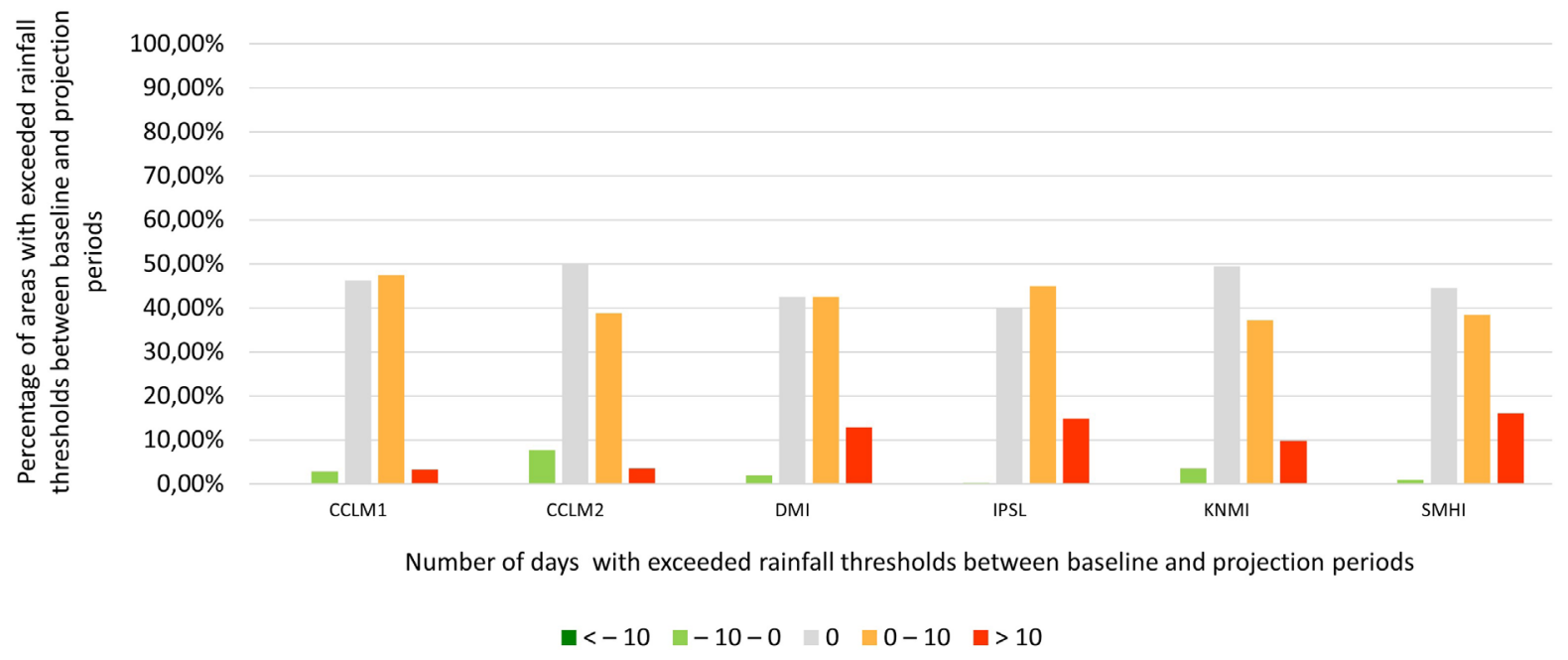

Fig. 3. Percentage of areas with exceeded rainfall thresholds between baseline and projection periods - comparison between six selected climate models simulations.

Sl. 3. Delež površine s preseženimi sprožilnimi količinami, ki ustrezajo razredu spremembe v številu dni nad sprožilno količino padavin med primerjalnim in projekcijskim obdobjem - primerjava med simulacijami šestih izbranih podnebnih modelov.

models. While the number of days with exceeded rainfall thresholds in 1981-2010 and 2041-2070 periods and the comparison (difference) between them are shown in the Fig. 4. Positive values of the number of days are represented by EG units where more precipitation events are expected in the mid-century (projection period), while negative values indicate EG units where there will be less extreme precipitation events than in the baseline period (1981-2010).

Comparing the number of precipitation days exceeding the exceeded rainfall threshold, i.e. $70 \mathrm{~mm}$ of rainfall, between the baseline and projection periods, the area fraction varies within each model (Fig. 3). The frequency of precipitation events in mid-century (2041-2070), when at least $70 \mathrm{~mm}$ of precipitation is expected, will be higher in areas in the north-west, north and east of Slovenia than in the baseline period. ARSO indicates a daily precipitation amount of $50 \mathrm{~mm}$ or more as very intense rainfall events (Bertalanič et al., 2019). In the case of a moderately optimistic release scenario, the number of days with such intense precipitation will start to increase in the west of the country. Considering the impact of climate change, more than 10 such precipitation events are expected to occur in the middle of the century only in smaller areas of Slovenia, covering 3 to $16 \%$ of the land (Figs. 3, 4, red areas), while up to 10 such events are expected in $37 \%$ to $47 \%$ of the land in the west, north and east of Slovenia according to the annual average (Figs. 3,4 , orange areas). Calculations of the impact of climate change on the frequency of precipitation events exceeding the rainfall threshold show that in the middle of the century these precipitation events will be lower than in the baseline period only in smaller areas of Slovenia (covering up to $8 \%$ ) (Figs. 3, 4, green areas). In recent years, Ujma Journal has reported that, on average, extreme precipitation events (short intense or prolonged rainfall) have caused landslides at least twice a year for the past 20 years (Ujma, 2000-2020). The Ujma Journal, published by the Administration of the Republic of Slovenia for Civil Protection and Disaster Relief, which is responsible for administrative and professional protection, rescue, relief and other tasks related to protection against natural and other disasters in Slovenia, annually collects the most important disaster events in the country, including precipitation-related events that triggered landslides. Although these results are not directly comparable due to uncertainties in climate change prediction models and information sources, as they are on the one hand events that actually occurred and on the other hand, predictions according to climate change prediction $\mathrm{RCP} 4.5$, it can be noted that the number of precipitation events that may trigger landslides in the mid-21st century is higher than the exact number of precipitation events that have triggered landslides in recent years. This finding is of particular concern because the prediction models consider all rainfall events with a threshold above $70 \mathrm{~mm}$, above which a landslide always occurs. 

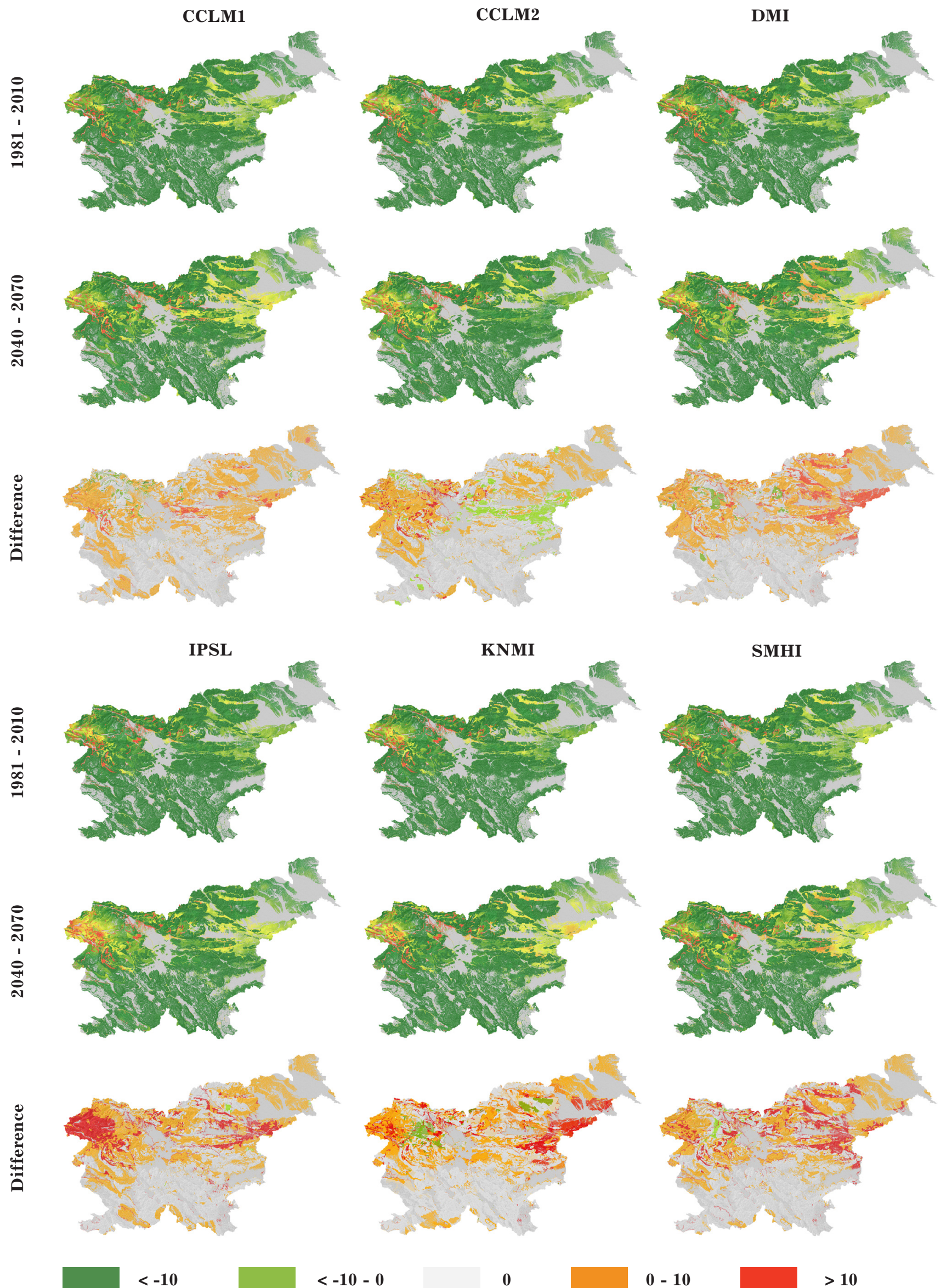

$\mathbf{0}$

0 - 10

$>10$

Fig. 4. Number of days with exceeded rainfall thresholds in the periods 1981-2010 and 2041-2070 and comparison (difference) between them.

Sl. 4. Število dni s preseženimi sprožilnimi količinami padavin v obdobjih 1981-2010 in 2041-2070 ter primerjava (razlika) med njimi. 
Table 2. Proportion of landslide areas in relation to the moderately optimistic scenario of greenhouse gas emissions between the baseline and projection periods - comparison between six selected climate models simulations.

Tabela 2. Deleži površine plazljivih območjih glede na zmerno optimistični scenarij izpustov toplogrednih plinov med primerjalnim in projekcijskim obdobjem - primerjava med simulacijami šestih izbranih podnebnih modelov.

\begin{tabular}{|c|c|c|c|c|c|c|c|}
\hline Class & $\begin{array}{c}\text { Climate change } \\
\text { impact on } \\
\text { landslides }\end{array}$ & $\begin{array}{c}\text { CCLM 1 } \\
1981-2010\end{array}$ & $\begin{array}{c}\text { CCLM } 1 \\
\text { 2041-2070 }\end{array}$ & $\begin{array}{c}\text { CCLM } 2 \\
1981-2010\end{array}$ & $\begin{array}{c}\text { CCLM } 2 \\
\text { 2041-2070 }\end{array}$ & $\begin{array}{c}\text { DMI } \\
1981-2010\end{array}$ & $\begin{array}{c}\text { DMI } \\
\text { 2041-2070 }\end{array}$ \\
\hline $\mathbf{0}$ & Negligible & $18,04 \%$ & $18,04 \%$ & $18,04 \%$ & $18,04 \%$ & $18,04 \%$ & $18,04 \%$ \\
\hline 1 & Very low & $71,17 \%$ & $68,37 \%$ & $71,26 \%$ & $69,05 \%$ & $71,82 \%$ & $63,57 \%$ \\
\hline 2 & Low & $5,33 \%$ & $5,04 \%$ & $5,93 \%$ & $6,39 \%$ & $5,87 \%$ & $6,38 \%$ \\
\hline 3 & Medium & $3,54 \%$ & $4,60 \%$ & $2,89 \%$ & $3,02 \%$ & $2,51 \%$ & $4,16 \%$ \\
\hline 4 & High & $1,43 \%$ & $3,06 \%$ & $1,34 \%$ & $2,53 \%$ & $1,26 \%$ & $4,22 \%$ \\
\hline 5 & Very high & $0,49 \%$ & $0,90 \%$ & $0,54 \%$ & $0,97 \%$ & $0,50 \%$ & $3,64 \%$ \\
\hline Class & $\begin{array}{c}\text { Climate change } \\
\text { impact on } \\
\text { landslides }\end{array}$ & $\begin{array}{c}\text { IPSL } \\
1981-2010\end{array}$ & $\begin{array}{c}\text { IPSL } \\
\text { 2041-2070 }\end{array}$ & $\begin{array}{c}\text { KNMI } \\
\text { 1981-2010 }\end{array}$ & $\begin{array}{c}\text { KNMI } \\
\text { 2041-2070 }\end{array}$ & $\begin{array}{c}\text { SMHI } \\
\text { 1981-2010 }\end{array}$ & $\begin{array}{c}\text { SMHI } \\
\text { 2041- 2070 }\end{array}$ \\
\hline $\mathbf{0}$ & Negligible & $18,04 \%$ & $18,04 \%$ & $18,04 \%$ & $18,04 \%$ & $18,04 \%$ & $18,04 \%$ \\
\hline 1 & Very low & $74,68 \%$ & $63,90 \%$ & $71,91 \%$ & $65,58 \%$ & $72,22 \%$ & $65,35 \%$ \\
\hline 2 & Low & $4,27 \%$ & $6,65 \%$ & $5,71 \%$ & $5,64 \%$ & $6,03 \%$ & $5,54 \%$ \\
\hline 3 & Medium & $1,66 \%$ & $5,41 \%$ & $2,49 \%$ & $4,45 \%$ & $2,41 \%$ & $4,45 \%$ \\
\hline 4 & High & $0,98 \%$ & $4,33 \%$ & $1,34 \%$ & $4,73 \%$ & $0,97 \%$ & $4,52 \%$ \\
\hline 5 & Very high & $0,38 \%$ & $1,68 \%$ & $0,51 \%$ & $1,56 \%$ & $0,33 \%$ & $2,10 \%$ \\
\hline
\end{tabular}

\section{Future patterns}

The results of the impact of climate change on the probability of landslides for the territory of Slovenia at a scale of 1: 250,000 are presented in tabular form (Table 2) and spatially with the percentage of the area in the baseline and projection periods for all six models simulations (Fig. 5).

In the moderately optimistic emissions scenario, an increased probability of landslides in classes ranging from low to very high probability is expected in case of all six climate models simulations at mid-century, although the proportions do not differ significantly. Areas with a very high to high probability of landslides will occupy $5 \%$ more land in the areas of eastern and northeastern Slovenia and in the area of the Idrijsko Cerkljansko and Škofjeloško hills than in the baseline period (Table 2, Fig. 5, purple areas). By mid-century, the moderate to low probability of landslides will be $7 \%$ higher overall in the areas of eastern, northeastern and northwestern Slovenia and in smaller parts of the Škofjeloško-Cerkljansko area (Table 2, Fig. 5, medium purple areas). In the middle of the century, the percentage of the area with a very low probability of landslides will decrease by up to $10 \%$ (Table 2, Fig. 5, blue areas). As expected, the proportion of area with a negligible probability of landslides does not change over either time period. These are areas where the natural conditions of the territory (geological structure, morphology) are such that landslides occur very rarely.

Komac and Ribičič (2006) defined $24 \%$ of the area as being at high to very high prone to landslides, considering only the natural geological and geomorphological background of the area. In this study these data were compiled together with rainfall, i.e. climate scenarios, and show that the probability of landslide occurrence in the mid-21st century is almost $8 \%$ higher than in the baseline period according to the susceptibility to landslides given by Komac \& Ribičič (2006).

Ciabatta et al. (2016) investigated the impact of climate change on landslide occurrence in Umbria, central Italy, using GCM projections RCP8.5 (the worst scenario) applied to an existing regional landslide early warning system (Ponziani et al., 2012) and assessed increase of landslide occurrence for $30 \%$ in the period 20402069. Comparing their results with the similar approach in this paper, except that we used a moderately optimistic climate scenario (RCP4.5), we found an increase in landslide probability of 5 


\section{CCLM1}
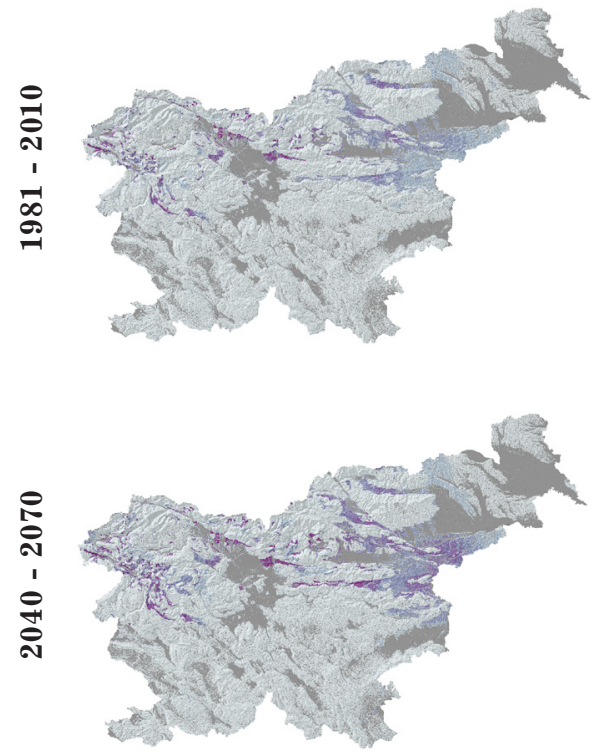

IPSL
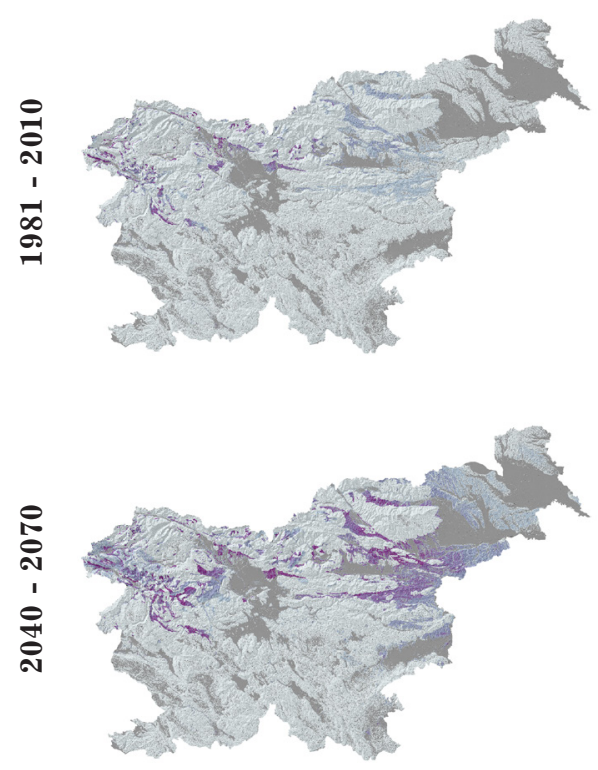

negligible
CCLM2
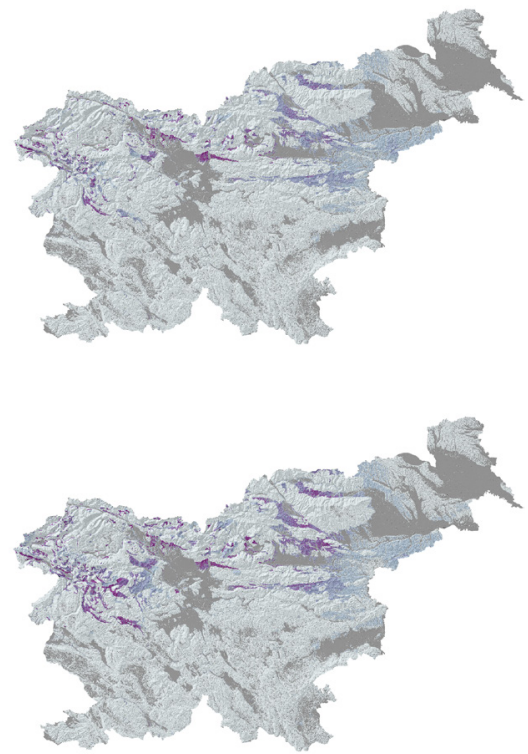

KNMI
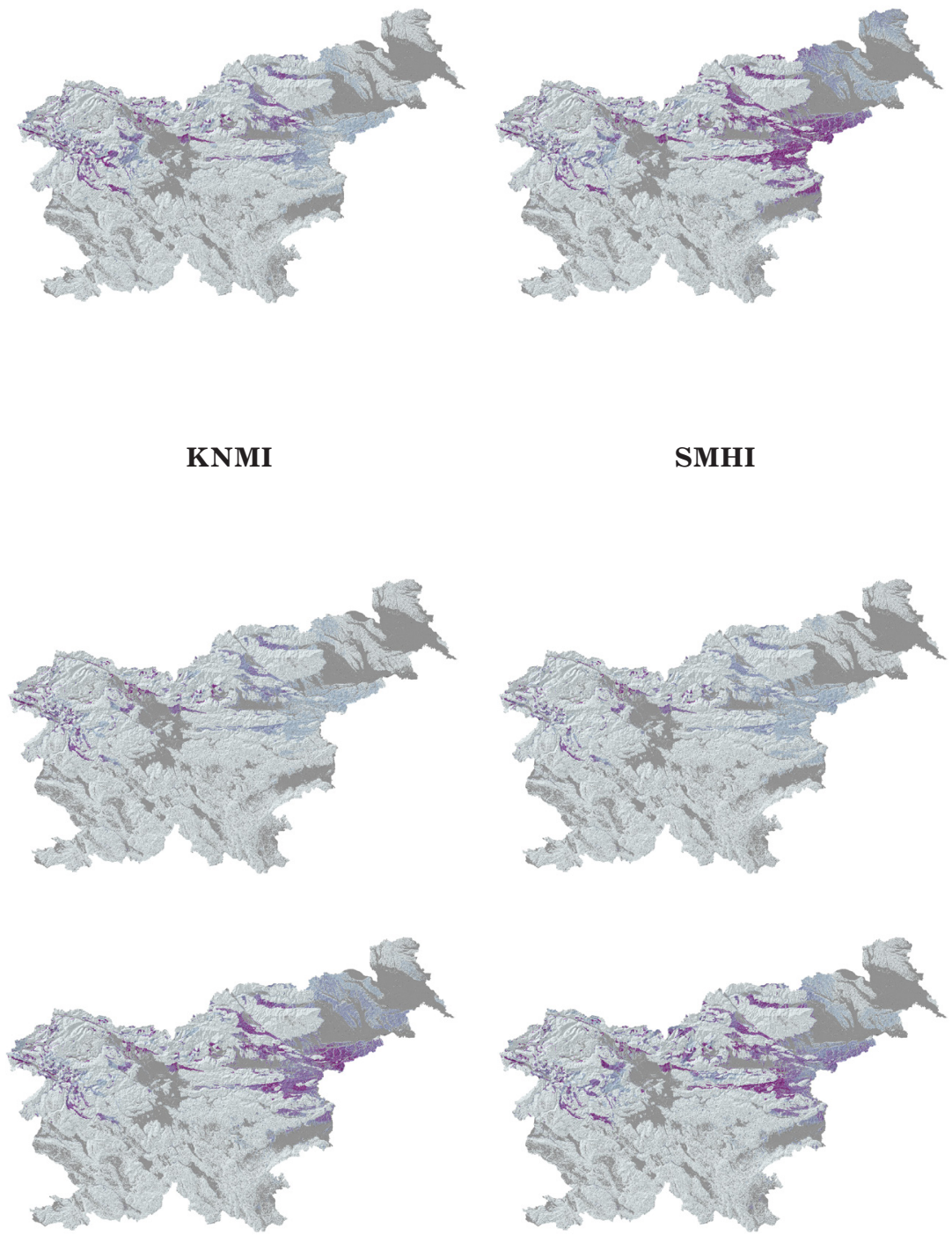

SMHI
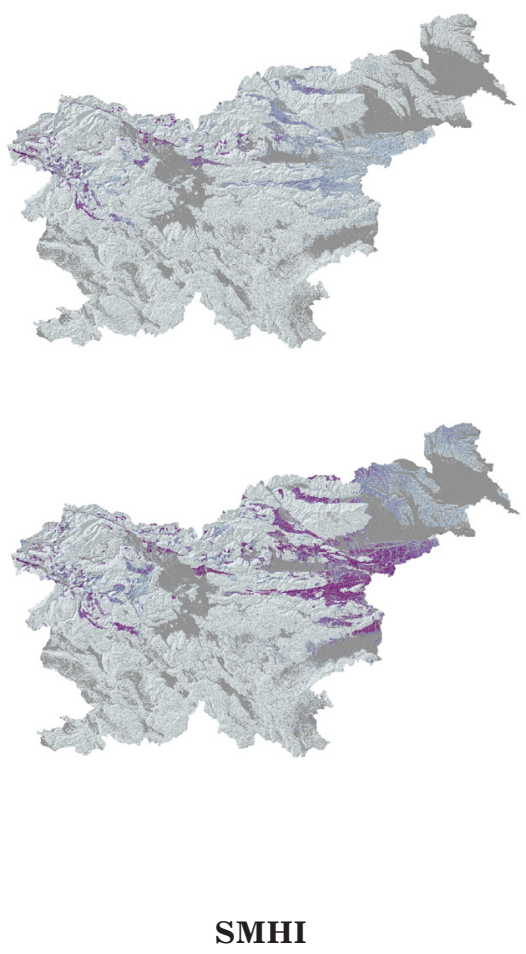

high very high

Fig. 5. The impact of climate change on the probability of landslides in the periods 1981-2010 and 2041-2070 for the territory of Slovenia for six models simulations. Landslide susceptibility is divided into 5 classes ranging from negligible to very high using an equal interval algorithm $(0,20)$.

Sl. 5. Vpliv podnebnih sprememb na verjetnost pojavljanja zemeljskih plazov v obdobjih 1981-2010 in 2041-2070 za območje Slovenije za šest modelov. Verjetnost pojavljanja plazov je razdeljena na 5 razredov od zanemarljive do zelo velike $\mathrm{z}$ uporabo algoritma enakih intervalov $(0,20)$. 
to $7 \%$ for the period from 2040 to 2070 . Based on the results of this study, we can assume that the use of RCP8.5 models on the territory of Slovenia would significantly increase the occurrence of landslides in the mid-21st century.

\section{Conclusions}

This paper highlights the impact of changing rainfall patterns in landslide-prone areas in Slovenia by the mid-21st century based on the RCP4.5 moderately optimistic climate scenario. The results indicate that the frequency of rainfall events in the mid-century (2041-2070), when at least $70 \mathrm{~mm}$ of rainfall is projected, will be higher in areas in the north-west, north and east of Slovenia. More than 10 such rainfall events are expected in smaller areas of Slovenia covering 3 to $16 \%$ of the area, while up to 10 such events are expected in $37 \%$ to $47 \%$ of areas in the west, north and east of Slovenia. Similarly, the results of the impact of climate change on landslides in Slovenia in the mid-century shows that landslides are more likely to occur in the areas of eastern and northeastern Slovenia and in the area of the Idrijsko-Cerkljansko and Škofjeloško hills. In these areas, about $12 \%$ more landslides are expected with respect to the baseline period.

The authors of the report "Climate change assessment in Slovenia until the end of the 21st century" provided by Bertalanič et al. (2019) clearly indicated that we can expect $20 \%$ more precipitation events in the middle of the century. They also found that a slightly larger increase in precipitation amount is expected in winter in eastern Slovenia. While in the other seasons, the trend and magnitude of precipitation change are strongly dependent on the release scenario and partly on the type of model, and the changes are mostly smaller than the natural variability of precipitation. Moreover, an increase in the intensity and frequency of extreme precipitation is also expected.

Since landslides are closely related to the rainfall distribution, intensity and duration of a rainfall event, the results of the assessment of climate change impacts on landslide occurrence depend strongly on the expected trends in rainfall changes. Predictions of how climate change will impact on landslides depend largely on the climate regime, the geomorphological characteristics of the area, and the geological setting in Slovenia. Gariano et al. (2016) highlighted also the long-standing human interventions in the country, which could speed the occurrence of landslides. The interaction between natural and human factors is complex and contributes to the uncertainty in assessing the impact of climate change on landslides. Despite potential uncertainties, this study is one of the first in the country to highlight the increasing likelihood of landslides in the mid-21st century as a result of extreme, more intense rainfall. Therefore, these findings should encourage decision makers to develop an adaptation strategy to manage the inevitable impacts and increase the resilience of natural and human systems to the current and future impacts of climate change.

\section{Acknowledgment}

We thank the Slovenian Research Agency (Research Program P1-0011 and research project J13024), Administration of the Republic of Slovenia for Civil Protection and Disaster Relief (MASPREM project) and the Ministry of Environment and Spatial Planning for funding this research.

\section{References}

Alvioli, M. \& Baum, R.L. 2016: Parallelization of the TRIGRS model for rainfall-induced landslides using the message passing interface. Environ. Modell. Software 81/C: 122-135. https://doi.org/10.1016/j.envsoft.2016.04.002

Benestad, R., Haensler, A., Hennemuth, B., Illy, T., Jacob, D., Keup-Thiel, E. \& Zsebeház, G. 2018: Guidance for EURO-CORDEX climate projections data use (EURO-CORDEX Guidelines Version 1.0 - 2017.08). https:// www.eurocordex.net/imperia/md/content/ csc/cordex/euro-cordex-guidelines-version1.0-2017.08.pdf

Bertalanič, R., Dolinar, M., Honzak, l., Lokošek, N., Medved, A., Vertačnik, G. \& Vlahović, Ž. 2019: Climate change projections for Slovenia over the 21st century: Temperature and precipitation summary. http://www.meteo.si/uploads/probase/www/climate/text/en/publications/OPS21_brosura_ENG.pdf

Bezak, N., Šraj, M. \& Mikoš, M. 2016: Copula-based IDF curves and empirical rainfall threshol$\mathrm{ds}$ for flash floods and rainfall-induced landslides. Journal of Hydrology, 541: 272-284. https://doi.org/10.1016/j.jhydrol.2016.02.058

Bezak, N., Brilly, M., Šraj, M. \& Mikoš, M. 2018: Intensity-duration-frequency curves for rainfall-induced shallow landslides and debris flows using copula functions: TXT-tool 2.386-1.1. In: Sassa, K., Tiwari, B., Liu, K.-F., 
McSaveney, M., Strom, A. \& Setiawan,H. (eds.): Landslide dynamics: ISDR-ICL landslide interactive teaching tools. Vol. 2, Testing, risk management and country practices. Berlin: Springer, 425-431. https://link.springer.com/ chapter/10.1007/978-3-319-57774-6_32

Bezak, N., Jemec Auflič, M. \& Mikoš, M. 2019: Application of hydrological modelling for temporal prediction of rainfall-induced shallow landslides. Landslides, 16/7: 1273-1283. https://doi.org/10.1007/s10346-019-01169-9

Buma, J. \& Dehn, M. 1998: A method for predicting the impact of climate change on slope stability. Environmental Geology, 35: 190-96. https://doi.org/10.1007/s002540050305

Bonnard, C., Tacher, L. \& Beniston, M. 2008: Prediction of landslide movements caused by climate change: modelling the behaviour of a mean elevation large slide in the Alps and assessing its uncertainties. In: Chen, Z., Zhang, J.M., Li, Z.K., Wu, F.Q. \& Ho, K. (eds.): Landslides and Engineering Slopes. From the Past to the Future, 217-227. https://doi. org/10.1201/9780203885284-c13

Borgatti, L. \& Soldati, M. 2010: Landslides as a geomorphological proxy for climate change: a record from the Dolomites (northern Italy). Geomorphology, 120: 56-64. https://doi. org/10.1016/j.geomorph.2009.09.015

Ciabatta, L., Camici, S., Brocca, L., Ponziani, F., Stelluti, F., Berni, N. \& Moramarco, T. 2016: Assessing the impact of climate-change scenarios on landslide occurrence in Umbria Region, Italy. J. Hydrol. https://doi. org/10.1016/j.jhydrol.2016.02.007

Chang, S.-H. \& Chiang, K.-T. 2011: The potential impact of climate change on typhoon triggered landslides in Taiwan, 2010-2099. Geomorphology, 133: 143-151. https://doi. org/10.1016/j.geomorph.2010.12.028

Coe, J.A. 2012: Regional moisture balance control of landslide motion: implications for landslide forecasting in a changing climate. Geology, 40/4: 323-326. https://doi.org/10.1130/ G32897.1

Coe, J.A. \& Godt, J.W. 2012: Review of approaches for assessing the impact of climate change on landslide hazards. In: Eberhardt, E., Froese, C., Turner, A.K. \& Leroueil, S. (eds.): Landslides and Engineered Slopes, Protecting Society Through Improved Understanding: Proceedings 11th International and 2nd North American Symposium on Landslides and Engineered Slopes, Banff, Canada 1. Taylor \& Francis Group, 3-8 June London: 371-377.
Collison, A., Steven W., Griffiths, J. \& Dehn, M. 2000: Modelling the impact of predicted climate change on landslide frequency and magnitude in SE England. Engineering Geology, 55: 205-18.

Comegna, L., Picarelli, L., Bucchignani, E. \& Mercogliano, P. 2013: Potential effects of incoming climate changes on the behaviour of slow active landslides in clay. Landslides, 10/4: 373-391. https://doi.org/10.1007/ s10346-012-0339-3

Crozier, M. J. 2010: Deciphering the effect of climate change on landslide activity: A review, Geomorphology, 124: 260-67.

Dikau, R. \& Schrott, L. 1999: The temporal stability and activity of landslides in Europe with respect to climatic change (TESLEC): main objectives and results, Geomorphology, 30: 1.

Dixon, N. \& Brook, E. 2007: Impact of predicted climate change on landslide reactivation: case study of Mam Tor, UK. Landslides, 4: 137-147. https://doi.org/10.1007/s10346-006-0071-y

Gariano, S.L. \& Guzzetti, F. 2016: Landslides in a changing climate'. Earth-Science Reviews, 162: 227-52.

Gariano, S.L., Brunetti, M.T., Iovine, G., Melillo, M., Peruccacci, S., Terranova, O., Vennari, C. \& Guzzetti, F. 2015: Calibration and validation of rainfall thresholds for shallow landslide forecasting in Sicily, Southern Italy. Geomorphology, 228: 653-665. https://doi. org/10.1016/j.geomorph.2014.10.019

Gassner, C., Promper, C., Begueria, S. \& Glade, T. 2015: Climate change impact for spatial landslide susceptibility. In: Lollino, G., Manconi, A., Clague, J., Shan, W. \& Chiarle, M. (eds.): Engineering Geology for Society and TerritoryClimate Change and Engineering Geology 1. Springer International Publishing: 429-433.

Glade, T. 2003: Landslide occurrence as a response to land use change: a review of evidence from New Zealand. Catena, 51/3-4: 297-314. https://doi.org/10.1016/ s0341-8162(02)00170-4 Guzzetti, F., Peruccacci, S., Rossi, M. \& Stark, C.P. 2007: Rainfall thresholds for the initiation of landslides in central and southern Europe. Meteorog. Atmos. Phys., 98: 239-267. https://doi.org/10.1007/s00703-007-0262-7

Heerdegen, R. 1991: Book reviews: Houghton, J.T., Jenkins, G.J. and Ephraums, J.J. 1990: Climate change - the IPCC scientific assessment. Cambridge: Cambridge University Press for the Intergovernmental Panel on Climate Change (World Meteorological 
Organisation/United Nations Environmental Programme).

IPCC 2018: Summary for Policymakers. In: Global Warming of $1.5^{\circ} \mathrm{C}$. An IPCC Special Report on the impacts of global warming of $1.5^{\circ} \mathrm{C}$ above pre-industrial levels and related global greenhouse gas emission pathways, in the context of strengthening the global response to the threat of climate change, sustainable development, and efforts to eradicate poverty [Masson-Delmotte, V., P. Zhai, H.-O. Pörtner, D. Roberts, J. Skea, P.R. Shukla, A. Pirani, W. Moufouma-Okia, C. Péan, R. Pidcock, S. Connors, J.B.R. Matthews, Y. Chen, X. Zhou, M.I. Gomis, E. Lonnoy, T. Maycock, M. Tignor, and T. Waterfield (eds.)]. World Meteorological Organization, Geneva, Switzerland, 32 pp.

Jakob, M. \& Lambert, S. 2009: Climate change effects on landslides along the southwest coast of British Columbia. Geomorphology, 107/3-4: 275-284. https://doi.org/10.1016/j. geomorph.2008.12.009

Jemec Auflič, M. \& Komac, M. 2013: Rainfall patterns for shallow landsliding in perialpine Slovenia. Natural hazards, 67/3: 1011-1023. https://doi.org/10.1007/s11069-011-9882-9

Jemec Auflič, M., Šinigoj, J., Krivic, M., Podboj, M., Peternel, T. \& Komac, M. 2016: Landslide prediction system for rainfall induced landslides in Slovenia (Masprem) = Sistem opozarjanja na nevarnost proženja zemeljskih plazov v Sloveniji (Masprem). Geologija, 59/2: 259271. https://doi.org/10.5474/geologija.2016.016 Jemec Auflič, M., Šinigoj, J., Krivic, M. \& Podboj, M. 2018: Challenges for operational forecasting of rainfall-induced landslides in Slovenia. In: Jemec Auflič, M., Mikoš, M. \& Verbovšek, T. (eds.): Advances in landslide research: proceedings of the 3rd Regional Symposium on Landslides in the Adriatic Balkan Region, 11-13 October 2017, Ljubljana, Slovenia. Geological Survey of Slovenia: 71-75.

Jordanova, G., Gariano, S.L., Melillo, M., Peruccacci, S., Brunetti, M.T. \& Jemec Auflič, M. 2020: Determination of Empirical Rainfall Thresholds for Shallow Landslides in Slovenia Using an Automatic Tool. Water, 12/5:1449. https://doi.org/10.3390/w12051449

Komac, M. 2005: Rainstorms as a landslide-triggering factor in Slovenia. Geologija, 48/2: 263279. https://doi.org/10.5474/geologija.2005.022

Komac, M. \& Ribičič, M. 2006. Landslide susceptibility map of Slovenia at scale 1:250,000 $=$ Karta verjetnosti pojavljanja plazov $\mathrm{V}$ Sloveniji v merilu 1:250.000. Geologija,

\section{9/2: 295-309. https://doi.org/10.5474/} geologija.2006.022

Komac, M., Šinigoj, J., Jemec Auflič, M., Čarman, M. \& Krivic, M. 2013: Landslide hazard forecast in Slovenia - MASPREM. In: Mihalić Arbanas, S. \& Arbanas, Ž. (eds.): Landslide and flood hazard assessment, 1st Regional Symposium on Landslides in the AdriaticBalkan Region with the 3rd Workshop of the Croatian-Japanese Project "Risk Identification and Land-Use Planning for Disaster Mitigation of Landslides and Floods in Croatia", Zagreb, Croatia from March 6th to 9th, 2013: 225-23.

Malet, J.-P., Remaître, A., Maquaire, O., Durand, Y., Etchevers, P., Guyomarch, G., van Déqué, M. \& Beek, L.P.H. 2007: Assessing the influence of climate change on the activity of landslides in the Ubaye Valley. In: McInnes, R., Jakeways, J. \& Fairbank, H. (eds.): Landslides and Climate Change: Challenges and Solutions, Proceedings of the International Conference on Landslides and Climate Change. Taylor \& Francis, Ventnor, Isle of Wight, 21-24 May 2007, UK: 195-205.

Malet, J.-P., van Asch, Th.W.J., van Beek, R. \& Maquaire, O. 2005: Forecasting the behaviours of complex landslides with a spatially distributed hydrological model. Nat. Hazards Earth Syst. Sci., 5/1: 71-85. https:// doi.org/10.5194/nhess-5-71-2005

McInnes, R., Jakeways, J., Fairbank, H. \& Mathie, E. 2007: Landslides and Climate Change: Challenges and Solutions, Proceedings of the International Conference on Landslides and Climate Change. Taylor \& Francis, Ventnor. https://doi.org/10. 1201/noe0415443180

Paranunzio, R., Laio, F., Chiarle, M., Nigrelli, G. \& Guzzetti, F. 2016: Climate anomalies associated to the occurrence of rockfalls at high-elevation in the Italian Alps. Nat. Hazard Earth Sys. Sci. Discuss. https://doi. org/10.5194/nhess-2016-100

Ponziani, F., Pandolfo, C., Stelluti,M., Berni, N., Brocca, L. \& Moramarco, T. 2012: Assessment of rainfall thresholds and soilmoisturemodeling for operational hydrogeological risk prevention in the Umbria region (central Italy). Landslides, 9: 229-237.

Rebetez, M., Lugon, R. \& Baeriswyl, P.-A. 1997: Climatic change and debris flows in high mountain regions: the case study of the Ritigraben torrent (Swiss Alps). Clim. Chang. 36: 371389. https://doi.org/10.1023/A:1005356130392 
Rianna, G., Zollo, A.L., Tommasi, P., Paciucci, M., Comegna, L. \& Mercogliano, P. 2014: Evaluation of the effects of climate changes on landslide activity of Orvieto clayey slope. Procedia Earth Plan. Sci., 9. 54-63. https:// dx.doi.org/10.1016/j.proeps.2014.06.017

Ribičič, M., Šinigoj, J. \& Komac, M. 2003: New general engineering geological map of Slovenia. Geologija, 46/2: 397-404.

Rosi, A., Peternel, T., Jemec Auflič, M., Komac, M. \& Casagli, N. 2016: Rainfall thresholds for rainfall-induced landslides in Slovenia. Landslides, 13: 1571-1577. https://doi. org/10.1007/s10346-016-0733-3

Schmidt, J. \& Glade, T. 2003: Linking global circulation model outputs to regional geomorphic models: a case study of landslide activity in New Zealand. Clim. Res., 25: 135-150. https://doi.org/10.3354/cr025135

Schmidt, J. \& Dikau, R. 2004: Modeling historical climate variability and slope stability. Geomorphology, 60: 433-447. https://doi. org/10.1016/j.geomorph.2003.11.001

Sidle, R.C. \& Ochiai, H. 2006: Landslides: Processes, Prediction, and Land Use (American Geophysical Union: United States).

Sidle, R.C. \& Dhakal, A.S. 2002: Potential effects of environmental change on landslide hazards in forest environments. In: Sidle, R.C. (ed.): Environmental Change and Geomorphic Hazards in ForestsIUFRO Research Series 9. CABI Publishing, Wallingford, Oxen, UK: 123-165. https://doi. org/10.1079/9780851995984. 0123

Stoffel, M., Tiranti, D. \& Huggel, C. 2014: Climate change impacts on mass movements - case studies from the European Alps. Sci. Total Environ., 493: 1255-1266. https://doi. org/10.1016/j.scitotenv.2014.02.102

Tacher, L. \& Bonnard, C. 2007: Hydromechanical modelling of a large landslide considering climate change conditions. In: McInnes, R., Jakeways, J., Fairbank, H. \& Mathie, E. (eds.): Landslides and Climate Change: Challenges and SolutionsProceedings of the International Conference on Landslides and Climate Change. Taylor \& Francis, Ventnor: 131-141

Tommasi, P., Pellegrini, P., Boldini, D. \& Ribacchi, R. 2006: Influence of rainfall regime on hydraulic conditions and movement rates in the overconsolidated clayey slope of the Orvieto hill (Central Italy). Can. Geotech. J. 43: 70-86. https://doi.org/10.1139/ cgj2012-0121

Trauth, M.H., Alonso, R.A., Haselton, K.R., Hermanns, R.L. \& Strecker, M.R. 2000: Climate change and mass movements in the NW Argentine Andes. Earth Planet. Sci. Lett. 179/2: 243-256. https://doi.org/10.1016/ S0012-821X(00)00127-8

Ujma, 2000-2020: Revija za vprašanja varstva pred naravnimi in drugimi nesrečami. Uprava RS za zaščito in reševanje, Ministrstva za obrambo, ISSN 0353-085X, Ljubljana. http:// www.sos112.si/slo/page.php?src=sv61.htm

van Vuuren, D., Edmonds, J., Kainuma, M., Riahi, K., Thomson, A., Hibbard, K., George C. Hurtt, T., Krey, V., Lamarque, J-F., Masui, T., Meinshausen, M., Nakicenovic, N., Steven J. \& Smith Rose, S. 2011: The representative concentration pathways: an overview. Climatic Change, 109: 5-31

Wasowski, J., Lamanna, C. \& Casarano, D. 2010: Influence of land-use change and precipitation patterns on landslide activity in the Daunia Apennines, Italy. Q. J. Eng. Geol. Hydrogeol., 43: 387-401. https://doi. org/10.1144/1470-9236/08-101

White, I.D., Mottershead, D.N. \& Harrison, J.J. 1996: Environmental Systems, 2nd Edition. London: Chapman \& Hall London: 616 p.

Winter, M.G., Dent, J., Macgregor, F., Dempsey, P., Motion, A. \& Shackman, L. 2010: Debris flow, rainfall and climate change in Scotland. Q. J. Eng. Geol. Hydrogeol., 43: 429-446. https:// doi.org/10.1144/1470-9236/08-108

Zollo, A.L., Rianna, G., Mercogliano, P., Tommasi, P. \& Comegna, L. 2014: Validation of a simulation chain to assess climate change impact on precipitation induced landslides. In: K. Sassa, K., Canuti, P., Yin, Y. (eds.), Landslide Science for a Safer Geoenvironment 1. Springer International Publishing, 287-292.

Yin, Z., Qin, X., Yin, Y., Zhao, W. \& Wei, G. 2014: Landslide developmental characteristics and response to climate change since the last glacial in the upper reaches of the Yellow river, NE Tibetan plateau. Acta Geol. Sin. (English edition), 88/2: 635-646. https://doi. org/10.1111/1755-6724.12219 